\title{
Poverty Assessment in Urban Area of Jodhpur District in Western Arid Region of Rajasthan
}

\author{
Satya Prakash Sharma
}

\author{
Shree Nakoda Parshwanath Jain Mahavidyalaya, Jodhpur, India
}

\begin{abstract}
An attempt has been made to assess the poverty status in rural area of Jodhpur district of western Rajasthan. Two villages were randomly selected fall in the radius of $20 \mathrm{~km}$ from the Jodhpur city whereas another two villages were selected $60 \mathrm{~km}$ far from Jodhpur city with poor infrastructure facility and poor non-farm employment. 30 respondents were randomly selected from each selected village.A total of 120 respondents were selected from four village for the study. Simple tabulation method was used. For determining the poverty status, income method was used. From the study, it is revealed that agriculture, livestock, non-farm-labor activities are the main factor for poverty assessment. Size of land holding is a crucial factor. Marginal and small land holding couple with low income, are the main reason for poverty. The percentage of earners in the family size groups and percentage of dependents is inversely proportionate.
\end{abstract}

Keywords- Poverty Assessment, western Rajasthan, BPL.

\section{INTRODUCTION}

Poverty is very complex and complicated problem and faced by various developing and under-developing countries. A simple meaning of poverty is the inability to secure minimum requirement for life, health and efficiency. These requirements include minimum human needs in respect of food, clothing, housing, education and health. The planners have been using a term 'Poverty line'. Those who can fulfill their minimum needs are 'above poverty' line and those who cannot are 'below poverty line (BPL). IN 1987-88, 30\% population was below poverty line; therefore large number of people in our region, particularly in the rural area is extremely poor as compared to the urban inhabitants. Poverty affects the general health and efficiencies of the people and resulted into low productivity. This inadequate economic development causes more poverty and it continues, ultimately forms the vicious civil. Problems of poverty, hunger, malnutrition, illiteracy, unemployment and poor medical facilities are enhancing the economic inequality. It means vast disparities in the income of different sections of people and it's also mean different levels of standard of living in rural as well as in urban areas.
There is a wide difference exists in estimate of poverty because of the differences in methodologies, data adjustments and pre-deflation used. Studies on poverty in India began with DadadhaiNaoraoji in the $19^{\text {th }}$ Century (Naoroji 1962). The major work on poverty estimates during the pre-independence period is that of V.K.R.V. Rao (1936) who revised Naorojiestimates of per capita income. Mukherjee (1969) updated the poverty estimate of Naoroji and Rao at 1948-49 prices than laying the foundation of further work on this subject in independent India. Further, in-depth studies on poverty in independent India are by Charan Singh (1964) and Tirlok Singh (1969). After the publicaton of Myrdal's Asian Drama in 1969 when stalwarts like Dandekar and Rath (1971) and Dandekar (1980) took up the burden of the theme.

In India the fruits of growth are largely distributed in favour of rich despite development of agricultural and industrial sector and initiation and spread of various development programs then remains a vast number of people whose economic conditions seem to have remained more or less stagnant if not deteriorated absolutely. NCAEA (1980), Minhas, B.S. (1971). Hanumantha Rao (1972) and Bhalla and Chadha (1974) reveal glaring inequalities in the distribution of income.

It is an accepted fact that there are large disparities both in the income and assets distribution. All over the country there is glaring evidence of concentration of wealth Considerable interest had been shown in equalities in India. Besides the government and other research bodies such as Reserve Bank of India, The National Council of Applied Economic Research. National Sample Survey organization and several scholars Bapana 1975; Bapana and Shah 1973, PhukanUmanuda 1975, Bhattacharya Pranab 1979 and Varghese 1987 have made significant contribution in this regard.

\section{METHODOLOGY AND SAMPLE DESIGN}

A two stage stratified sampling procedure is adopted to select the sample households. The sample included adequate proportion of social class and their working status to ensure comparison for ascertaining the effects of inequality and poverty. Sample selection is done in two stages; stage one refers to selection of urban blocks of Jodhpur city and households were selected in stage two. 5 
wards are selected for the study in urban, out of these 2 wards are taken inside the old boundary wall and 3 wards are from outside the main city area. A total of 120 respondents were selected from four village for the study.

Table.1: Distribution of sample household according the main occupation of income

\begin{tabular}{|l|c|}
\hline Occupation & Urban \\
\hline Category-I & $3(2.50)$ \\
\hline Category-II & $46(38.33)$ \\
\hline Category-III & $31(25.84)$ \\
\hline Category-IV & $40(33.33)$ \\
\hline Total & $120(100.00)$ \\
\hline
\end{tabular}

Note: Figures in parenthesis are percentages

\section{TOOLS AND TECHNIQUE}

Income method was used to find out the poverty status of selected respondents. Income from different sources were collected.

The data for the study was collected using a wellstructured exhaustive schedule through personal interview of adult male/female covering all the aspect of the study. Simple tabulation method was used. The selected respondents were categories in four different groups as follows and same are presented in the Table 1.

Category I: Income from farming comprises agriculture, livestock and allied activities (farming).
Category II: Income from agricultural and nonagricultural labourers, collies, hand-card puller, horse/bullock cart driver, vendor, hawker, masonry etc. The wages included cash and kind(Wage earners).

Category III: Income from occupations consists of, paltry/tea shop, owner, artisans, black smith, gold smith, carpenter, tailor etc (Business and crafts).

Category IV: Income includes occupation, college, school/university teacher etc in government and private official, who get regular services from public or private institutions.

\section{RESULTS AND DISCUSSION}

Distribution of urban sample households according to different source(s) of income is given in Table 2. Most of the households earn income from than one source. Wages, salary and business and craft are the main sources of income in the urban area of Jodhpur. Salary (private and government) is one of the main occupations of urban area. As such 22 per cent of the households have reported having received income by working as wage-labourers. The major chunk of income, 39.85 per cent, comes from salaries followed by business and craft and wages, which account 29.51 and 21.78 per cent respectively of total income. The share contributed to total income by daring and agriculture is 2.77 and 0.11 per cent respectively. House property and pensions contributes only 5.98 per cent in the total income.

Table.2: Composition of income of the sample urban households

\begin{tabular}{|l|c|c|c|}
\hline Income source & Percentage of household & Income Rs./Household & \% age of Total income \\
\hline Wages & 50.83 & 17893 & 21.78 \\
\hline Salaries & 45.00 & 32746 & 39.85 \\
\hline Business \& Craft & 24.17 & 24247 & 29.51 \\
\hline Daring & 0.83 & 2278 & 2.77 \\
\hline Agriculture & 0.81 & 90 & 0.11 \\
\hline Transfer & 15 & 4909 & 5.98 \\
\hline Total & & 82163 & \\
\hline
\end{tabular}

Analysis of the data regarding the earners and dependent in sample households (Table 2) revealed that larger percentage of dependents are found in households having 7 to 8 and 11 and more than 11 members. Generally, dependent population increases with the family size. The depending ratio (i.e. ration of dependents to earners) works out maximum (3.84) in family size group of 11 and more ad minimums in the family size group 1-2 (0.55). The average dependency ratio for the entire sample household is 2.98 .

Table.3: Percent distribution of economic status and dependency ratio of urban sample household

\begin{tabular}{|l|c|c|c|}
\hline Family Size & Earners & Dependents & Dependency \\
\hline $1-2$ & 64.29 & 35.71 & 0.55 \\
\hline $2-4$ & 32.93 & 67.07 & 2.04 \\
\hline $5-6$ & 25.25 & 74.75 & 2.96 \\
\hline $7-8$ & 21.38 & 78.62 & 3.67 \\
\hline $9-10$ & 23.40 & 76.60 & 3.27 \\
\hline
\end{tabular}




\begin{tabular}{|l|l|l|l|}
\hline 11 and above & 20.63 & 79.37 & 3.84 \\
\hline Total & 25.10 & 74.90 & 2.98 \\
\hline
\end{tabular}

Distribution of urban sample households into different annual gross income groups and number of earners in the respondent's households are presented in Table 3 . It is clear from the table that 70 per cent of households have one earning member, followed by two earners (17.0 per cent), three earners ( 9 per cent) and four and more than earners (4 per cent). It is observed that among the households having one earners income up to Rs. 50,000,
50 per cent households have one earner only. The mean number of earners varied from 1.00 to 2.50 and mean annual gross income per household is Rs. 54,173. Thus, table 4 reveals that there is positive relationship between the number of earners in a households and its annual gross income. Larger the number of earners have more average income.

Table.4: Distributions of urban sample household by gross income and number of earner in the family

\begin{tabular}{|l|c|c|c|c|c|}
\hline Income group & One earner & Two earners & Three earners & Four earners & No. of earners \\
\hline Less than 25,000 & $7(8.43)$ & 0 & 0 & 0 & 1.00 \\
\hline $25,000-30,000$ & $15(18.08)$ & $1(4.76)$ & 0 & 0 & 1.06 \\
\hline $30,000-35,000$ & $3(3.60)$ & $1(4.76)$ & 0 & 0 & 1.25 \\
\hline $35,000-40,000$ & $7(8.43)$ & 0 & 0 & 0 & 1.00 \\
\hline $40,000-50,000$ & $10(12.05)$ & $5(23.81)$ & $1(9.09)$ & $1(20.00)$ & 1.59 \\
\hline $50,000-70,000$ & $13(15.66)$ & $3(14.29)$ & $2(18.18)$ & 0 & 1.39 \\
\hline $70,000-1,00,000$ & $14(16.87)$ & $4(19.04)$ & 0 & 0 & 1.22 \\
\hline $100,000-150,000$ & $9(10.84)$ & $3(19.05)$ & $5(45.46)$ & $3(60.00)$ & 2.10 \\
\hline $150,000-200,000$ & $1(1.20)$ & $4(19.05)$ & $2(18.18)$ & 0 & 2.14 \\
\hline More than 200,000 & $4(4.82)$ & 0 & $1(9.09)$ & $1(20.00)$ & 2.50 \\
\hline Total & $83(100.00)$ & $21(100.00)$ & $11(100.00)$ & $5(100.00)$ & $1.52(100.00)$ \\
\hline
\end{tabular}

The cause of poverty, however, does not appear to be the celebrated theorem of demographic pressure on the household resources. It clears from the Table 4 that highest number of household (45 per cent) fall in the family size 5-6 members and they contribute 25.40 per cent of total income with an average income Rs. 65,547. It is observed that an equal number of 18.33 per cent each households are falling in the family size groups 3-4 and 78 are earning average mean R. 93,739 and Rs. 113,830 respectively. The average annual income per household is varied from Rs. 32,000 to Rs. 131,625. The table 4 shows that average annual households income tends to increase with the size of family $(r=0.85)$. The increase in the percentage share of income with increasing size of the household is also evidenced, barring the exceptions. It is difficult to pinpoint the reason of apparent contradiction in the popular relation household income and size. It is perhaps owing to the fact that larger household in this case implies more earning members.

Table.5: Distribution of urban sample household by family size

\begin{tabular}{|l|c|c|c|c|c|c|c|}
\hline Family size & $\begin{array}{c}\text { Percent of } \\
\text { households }\end{array}$ & $\begin{array}{c}\text { Percent share } \\
\text { of income }\end{array}$ & Salaries & $\begin{array}{c}\text { Business } \\
\text { \& Crafts }\end{array}$ & Wages & Others & $\begin{array}{c}\text { Average annual } \\
\text { household income }\end{array}$ \\
\hline $1-2$ & 7.5 & 2.92 & 6133 & 9200 & 15333 & 1334 & 32000 \\
\hline $3-4$ & 18.33 & 20.91 & 59103 & 17336 & 10273 & 7027 & 93739 \\
\hline $5-6$ & 45.00 & 35.91 & 27105 & 15730 & 1585 & 6827 & 65547 \\
\hline $7-8$ & 18.33 & 25.40 & 31107 & 55273 & 17545 & 9905 & 113830 \\
\hline $9-10$ & 4.17 & 4.18 & 37200 & 12000 & 32800 & 500 & 82500 \\
\hline More than 11 & 6.67 & 10.68 & 30000 & 40000 & 46925 & 14700 & 131625 \\
\hline All classes & 100.00 & 100.00 & 32746 & 24247 & 17893 & 7277 & 82163 \\
\hline
\end{tabular}

Table 5 presents the average annual gross income distribution of urban households by level of income. It is clear from the table that only 3 households are earning income from dairying and agriculture, fall in middle income group (i.e. Rs. 70,000-100,000 and 100,000 to
$150,000)$ with average annual gross income per household for this category is Rs. 89,000.

The spread of the incomes achieved by household engaged in business and craft activities varied from Rs. 18,000 to 600,000 . The number of households earning 
between Rs. 50,000 to Rs. 100,000 with average income of Rs. 71,625 is highest at 45.14 per cent. It is followed by 12.90 per cent of households in the income class Rs. 100,000 -Rs. 150,000 . It is observed that an equal number of 9.68 per cent (each) household are falling the income group of Rs. 25,000-35,000, Rs. 40,000-50,000 and Rs. 150,000 - Rs. 200,000 . Similarly equal number of 3.23 per cent (each) families are falling in less than Rs. 25,000, Rs. 30,000 - Rs. 35,000 , Rs. $35,000-40,000$ and in more than two lakhs income groups

In case of salary earners households, the maximum (30 per cent) earned income between Rs. 100,000 to Rs. 150,000 followed by 20 per cent fall in the income group of Rs. 70,000 to Rs. 100,000. No salary earner households earned less than Rs. 25,000 . There are only 10 per cent urban salary earners households in the income of less than Rs. 40,000 with their average amounting to Rs. 33,000 and they contribute 7.96 per cent of the total income. 70 per cent of salary earners households fall fall in middle income group and their share to total income is 58.55 per cent and 20 per cent fall in higher income group and they contribute 38.5 per cent of their total income. The average annual gross income for this category ranged from Rs. 29,400 to Rs. 265,515 .

The wage earners households are distributed between Rs. 20,933 at start and Rs. 210,000 at the end of the other scale. The highest number of urban families that is 26.09 per cent tare falling in the income class of Rs. 40,000 to Rs. 50,000 with an average income of Rs. 46,808. More than half $(52.17 \%)$ urban families are earning less than Rs. 40,000 per annum followed by medium income group (45.66 per cent) and contribute 58.36 per cent of the total income.

Table.6: Distribution of urban sample households according to different income groups

\begin{tabular}{|c|c|c|c|c|c|c|c|c|c|c|c|c|c|c|c|}
\hline \multirow{2}{*}{$\begin{array}{l}\text { Income } \\
\text { group }\end{array}$} & \multicolumn{3}{|c|}{ Farm Households } & \multicolumn{3}{|c|}{ Wage Earner } & \multicolumn{3}{|c|}{ Business \& Craft } & \multicolumn{3}{|c|}{ Salary Earner } & \multicolumn{3}{|c|}{ Overall } \\
\hline & A & B & $\mathrm{C}$ & A & B & $\mathrm{C}$ & A & B & $\mathrm{C}$ & A & B & $\mathrm{C}$ & A & B & $\mathrm{C}$ \\
\hline$<25000$ & - & - & - & 13.04 & 5.73 & 20933 & 3.23 & 0.61 & 18000 & & - & - & 5.83 & 1.46 & 20514 \\
\hline $\begin{array}{l}25000- \\
30000\end{array}$ & - & - & - & 23.91 & 14.74 & 29364 & 9.68 & 2.90 & 28433 & 5.00 & 1.32 & 29000 & 13.33 & 4.74 & 29194 \\
\hline $\begin{array}{l}30000- \\
35000\end{array}$ & - & - & - & 4.35 & 3.10 & 34000 & 3.23 & 1.16 & 34000 & 2.50 & 0.78 & 34800 & 3.34 & 1.38 & 34200 \\
\hline $\begin{array}{l}35000- \\
40000\end{array}$ & - & - & - & 10.87 & 8.49 & 37200 & 3.23 & 1.23 & 36000 & 2.50 & 0.86 & 38400 & 5.83 & 2.64 & 37200 \\
\hline $\begin{array}{l}40000- \\
50000\end{array}$ & - & - & - & 26.09 & 25.63 & 46808 & 9.68 & 4.49 & 43933 & 5.00 & 1.94 & 43200 & 14.17 & 7.91 & 45876 \\
\hline $\begin{array}{l}50000- \\
70000\end{array}$ & - & - & - & 10.87 & 13.17 & 57700 & 22.57 & 14.51 & 60892 & 15.60 & 7.81 & 58125 & 15.00 & 10.79 & 59083 \\
\hline $\begin{array}{l}70000- \\
100000\end{array}$ & 66.67 & 55.06 & 73500 & 2.17 & 3.29 & 72000 & 22.57 & 19.63 & 82357 & 20.00 & 15.84 & 88412 & 15.00 & 15.24 & 83489 \\
\hline $\begin{array}{l}100000- \\
150000\end{array}$ & 33.33 & 44.94 & 12000 & 6.53 & 16.27 & 118800 & 12.90 & 16.37 & 120200 & 30.00 & 32.96 & 122637 & 16.67 & 24.63 & 121442 \\
\hline $\begin{array}{l}150000- \\
200000\end{array}$ & - & - & - & - & - & - & 9.68 & 18.66 & 182267 & 10.00 & 14.71 & 164135 & 5.83 & 12.22 & 172077 \\
\hline$>200000$ & - & - & - & 2.17 & 9.58 & 210000 & 3.23 & 20.43 & 600000 & 10.00 & 23.79 & 265515 & 5.00 & 18.99 & 312010 \\
\hline & 100.00 & 100.00 & 89000 & 100.00 & 100.00 & 47634 & 100.00 & 100.00 & 94730 & 100.00 & 100.00 & 58864 & 100.00 & 100.00 & 82163 \\
\hline
\end{tabular}
A: Percentage of Households
B: Percentage of income
C: Average income

From the above discussion, it is revealed that agriculture, livestock, non-farm-labor activities are the main factor for poverty assessment. Size of land holding is a crucial factor. Marginal and small land holding couple with low income, are the main reason for poverty. The percentage of earners in the family size groups and percentage of dependents is inversely proportionate.

\section{REFERENCES}

[1] Adelman, Irma (May 1975) "Development Economics - A Reassessment of Goal" American Economic Reviews.

[2] Ahluwalia M.S. "Income inequality some demonisms of the problem" Redistribution with growth by H. Chenery et-al. London, 1974. 
[3] Ahluwalia, M.S. (1978) "Rural Poverty and Agricultural Performance in India" Journal of Development Studies.

[4] Ahmed, M. and Bhattacharya, N. "Size Distribution of per capita personal income in India: 1950-57, 1960-61 and 1963-64" Economic and Political Weekly, Special Number, 1972.

[5] AmareshBagchi : "Redistribution Role of Taxation in India: An Appraisal". In T.N. Srinivasan and P.K. Bardhan (ed.) New Delhi, 1988.

[6] Atkinson, A.B. "On the Measurement of inequalities". Journal of Economic Theory. Volume 2, September, 1970.

[7] Awasthi, O.S.(Ed.) Income, Saving and capital formation in Rural India, Indian Economic Association 1984.

[8] Bal H.S. and Gurcharan Singh "Pattern of Income Distribution in Rural areas" Indian Journal of Agricultural Economics, Vol. 35(3), 1970 pp 81-91.

[9] Bardhan P.K. and T.N. Srinivasan "Income distribution pattern, trends and policies" Economic and Political weekly, Vol. 16(17), 1971-pp 877-881.

[10] Bardhan, P.K. (1973) "On the incidence of poverty in rural India of the sixties "Economic and Political Weekly, 8 (4-6): 245-254.

[11] Bardhan, P.K. "Poverty and Trickle Down in Rural India: A Quantitative Analysis" (Eds) IN J.W. Mellor and Gunvant M. Desai. Agricultural change and rural poverty, Delhi, 1986.

[12] Basu, Shreelekha. "Pattern of Asset Holdings In indie A study at Top Asset-Holders" Economic and Political Weekly. Volume XI. Number 26, July 10, 1979

[13] Bhattacharya. 8.8. Short-Term Income Distribution. The Macmillan Co. of India Ltd, New Delhi. 1975.

[14] Bhatty, I.Z. "Inequality \& Poverty in Rural India in T.N. Srinivasan \& P K. Bardhan (ed) op. cit., pp. 291-336.

[15] Birthae, P.S. and Singh, M.K. "Structure of Rural Income Inequality A study in western Uttar Pradesh. Indian Journal of Agricultural Economics Vol 50 (2). 1995. pp 168.175.

[16] Chakraborty. G. "Studies on size distribution of income and consumption- A Review". Margin. Volume 16. 4 Number 1. Oct. 1983.

[17] Choudhry, Uma Datta Roy. "Income, consumption and saving in urban and rural India" Review of Income and Wealth Series Vol. 14. Number 1. March 1968.

[18] Chenery. H. et.al. "Redistribution with Growth. Oxford University Press, London. 1974.

[19] Coffex, J. D. "Personal distribution of farmer's income by source and region" American Journal of
Agricultural Economics. Vol. 50(5). 1968. pp, 198396

[20] Coondoo and Dipankar "A comparison of consumer expediter pattern of India middle class and working class families" Presented to $12^{\text {th }}$ Indian econometric conference. Kanpur, 1972

[21]Dacosta. E.P.W. (1971) "A portrait of Indian Poverty in Fonseca". A.J. (Ed.) Challenge of Poverty in India, Vikas, New Delhi.

[22] Dahiya, L.N. "Asset Distribution among Rural Households" Eastern Economist. February 13. 1981.

[23] Dandekar, V.M. and Rath (1971) Poverty in India (Poona, Indian School of Political Economy Ahmed, M. "Size Distribution of per capita personal income in India 1956-57". In NRS Sarthy et al (eds) Papers on National House. 1965.

[24] Dandekar, V.M. and M. Rath "Poverty in India Dimension and Trends" Economic and Political weekly, Vol. 6(1), 1971 pp 22-40

[25] Dandekar, V.M. and Rath, Neelkantha "Poverty in India, Bombay 1971."

[26] Dantwala, M.L. Poverty in India : Then and Now, New Delhi, 1973.

[27]De, B.K., Amiya, Debanath, Rajib Ghosh, Atihudhi, H.N., Debnath, A. and Ghosh, R. "Environment and Ecology, 1998". 16:1, p. 11-14.

[28] Deshpande, S.S., Mishra, A. and Mishra, M. "Profile of expenditure pattern on food and non-food items for villagers of Bhopal district in Madhya Pradesh" Indian Journals of Nutrition and Deities, 2001, 38:2, p. 45-48.

[29] Friend, Irwin and Lieberman, L. "Short-term Assets Effects on Household Saving andConsumption" The Cross-section Evidence. The American Economic Review. Vol. LXVI, Number 1, Sept. 1975.

[30] Ganguli, A. (1960) "Studies on consumer behavior", Asia Publishing House Bombay.

[31] Ghatak, Anita: "An Aggregate Consumption Function for India 1950-51 to 1970-71. The Indian Journal of Economics. Vol. LXII, Number 245, October 1981.

[32] Government of India, Planning Commission: "Report of the Committee on Distribution of Income and Levels of Living" 1964.....Draft Fifth Five Year Plan, Vol. II, (1975-79).

[33] Govemment of India "Draft Second Five Year Plan (1956) Third Five Year Plan (1961) and Fourth Five Year Plan, Planning Commission 1969-74.

[34] Gupta, K.L. "Households savings in Financial Assets -A case study of India". The Indian Economic Journal. Vol. XVII, Numbers 4 and 5 June 1970. 
[35] I.L.O. "Employment, Income and Equality" A strategy for increasing productive employment in Kenya (1972).

[36] Indira, Hirway. "GaribiHatao: Can IRDP Do it? Economic and Political Weekly, March 30, 1985.

[37] Iyengar, N.S. and Mukherjee, M. "A Note on Derivation of size Distribution of Personal Household income from a size Distribution of Consumer Expenditure, 1957.

[38] Iyengar N.S. and Mukherjee. M. "A note on Derivation of size distribution of personnel Household income from size distribution of consumer expenditure. (1957)

[39] Kalla, Jagdeesh C. "Saving investment Behaviour of Farm-families-Udaipur district Rajasthan. Ph.D. Thesis Ohio State University, U.S.A. Vol. xxxviii, 5 (1977).

[40] Krishna, Raj "Reduction in poverty" Indian Express Chandigarh $9^{\text {th }}$ Jan., 1984 pp6.

[41] Lyudall. F.H. "The inequality of Indian incomes" Economic and Political weekly, June 1960.

[42] Mahajan, B.M. "Interracial Homogeneity of Consumer Behavior in India (ArthVijan March 71).

[43] Minhas, B.S. (1974). Planning and the poor. S. Chand and Company Ltd., New Delhi.

[44] National Council of Applied Economic Research (1962). AllIndia Rural; Household saving survey. Vol. I, Methodology.

[45] National Council of Applied Economic Research (NCEAR) (1962), Saving survey, methodology Vol. I (New Delhi).

[46] Ojha, P.D. (1970), "A configurations of Indian Poverty: Inequality and levels of living" Reserve Bank of India Bulletin, Jan, 1970.

[47] Panikar, P.G.K. (1970) "Rural saving in India" Published by Samaiya Publication Private Limited, Bombay.

[48] Paul, Mohinder "Rich and Poor in Rural Haryana." The Tribune July 13 and July 20 (1989). NACER. (1989) Household income and its Deposition.

[49] Prema, A. and Thomas, E.K. "Distribution of farm and non-farm income among rural households". Journal of Tropical Agriculture, 1998. 36; 1-2, p. 8788.

[50] Rai, K.N., Malkit Kaur, M.K. Chaudhary and Kusum Aggarwal. "Pattern of investment and capital formation in Haryana Agriculture" Report No.23, Department of Agricultural Economics (HAU), Hisar, 1989.

[51] Rajan V.T. and I.J. Singh "Farm income distribution and measure of income inequality"Agricultural Situation in India, Vol. 29, October, 1974 pp -554
[52]Rajaraman, Indira "Poverty, inequality and economic growth in rural Punjab, 1960-61 to 197071 Journal of development Studies Vol. 11(4), 1975 pp 125-137

[53] Rajendra, K., Prabhakaran, R. "Socio economic status of milk producers in a household district of Tamil Nadu. Indian Veterinary Journal 2000, 77:2, p. 157-158.

[54] Rajuladevi, A.K. "Food poverty and consumption among landless labour households." Economic and Political Weekly, 2001, 36: 28, p. 2656-2664.

[55] Ranadive, K.R. "Distribution of income trends in planning." Paper presented in a seminar on income Distribution, Indian Statistical Institute, February, 1973.

[56] Randhawa, "Green Revolution- Farms and Farming" The Tribune Chandigarh, March 11 to17, 1984 p-4.

[57] Rao, N.B. "Demographic correlates of poverty in tribal households." Indian Journal of Social work, 1996, 57: 2, p. 337-355.

[58] Reddy, V.K. and Rao, N.V.M. "Levels of Living and Inequality in Andhra Pradesh." Asian Economic Review, 1995, 37: 22, pp. 352-357.

[59] Report "All India debt and investment survey RBImonthly Bulletin", 1999, 53:5 p. 673-691.

[60] Sen B. "Regional dispersion of agricultural, income implication of new technology" Economic and Political weekly, December 27, 1969

[61] Sharma, A.C., Mehta, Prakash and Singh, J.N. "Impact of Technological Development on the Pattern of income Distribution" A case study of Ludhiana District. IndianJournal of Agricultural Economic, Vol. XXV1l No.4 pp. 51-55.

[62] Sharma, R.L., Sharma, H.R. and BrijBala"Inequality in the Distribution of Farm Assets in Himachal Pradesh, A Decomposition Analysis”. Indian Journal of Agricultural Economics. Vol. 49(4), 1994.

[63] Singh, Balbir"Role of occupational factors in household consumption" IER 3 (New Sectional) 2 Oct. 1968

[64] Singh, B.K. "Composition of income and its distribution pattern on farm households". Journal of Research, Birsa Agricultural University 2001, 13:2, p. 171-175.

[65] Singh, Katar "The impact of new Agricultural Technology on Farm Income Distribution in the Aligarh district of Uttar Pradesh" Indian Journal of Agricultural Economics, Vol. 28 (2) 1973, pp 1-11

[66] Singh, RP. andAsokan, . "Concepts and methods for estimating income in villages studies in semi arid Tropical of India Economic Programme, Progress Report 28 ICRISAT, November, (1981) 
[67] Susheela, H., Surendre, H.S. Padmaja, Naik, Anuradha. Joshi, Naik, P. and Joshi, A. "Prevalence of poverty in rurall households of Dharwad district" Karnataka Journal of Agricultural Science 2000, 13:1, p. 228-229.

[68] Taneja, Suresh Kumar "Saving and Investment Behavior of Rural households in Punjab. PhD. thesis (1987) pp. 102-105, K.U. Kurukshetra.

[69] Vaidyanathan, A. "Some Aspects of Inequalities in Living standard in Rural India" in TS. Srinivasan \& P.K. Bardhan (ed) op., cit. pp 215-241.

[70] Visaria Pravin (1980) "Poverty and living standards in Asia" Population and Development Review (New York), Vol. 6 No.2. 